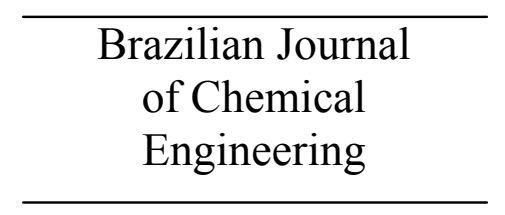

ISSN 0104-6632

Printed in Brazil

www.abeq.org.br/bjche

Vol. 25, No. 04, pp. 751 - 758, October - December, 2008

\title{
DISSOLUTION KINETICS OF ULEXITE PREPARED UNDER DIFFERENT CALCINATION TEMPERATURES
}

\author{
N. Demirkıran* and A. Künkül \\ Department of Chemical Engineering, Faculty of Engineering, Inonu University, \\ Phone: +(90) 422 3410010, Fax: +(90) 422 3410046, Malatya, 44280, Turkey. \\ E-mail: ndemirkiran@inonu.edu.tr
}

(Received: May 25, 2007 ; Accepted February 28, 2008)

\begin{abstract}
Ulexite is one of the boron minerals used as a raw material in the production of boron compounds. It contains a substantial amount of hydration water. Using calcination methods, the $\mathrm{B}_{2} \mathrm{O}_{3}$ grade of ulexite can be increased. In this study, the effect of calcination temperature on dissolution kinetics of ulexite in ammonium chloride solutions was investigated in a batch reactor employing the parameters of concentration, solid-to-liquid ratio and reaction temperature. It was found that the dissolution rate increased with increasing concentration and reaction temperature and with decreasing solid-to-liquid ratio. The highest dissolution rate was obtained with the sample calcined at $413 \mathrm{~K}$. It was determined that the dissolution rate fit to the secondorder pseudo-homogeneous model. The activation energy of this dissolution process was found to be 64.3 $\mathrm{kJ} / \mathrm{moL}$.

Keywords: Calcination; Ulexite; Dissolution kinetics; Ammonium chloride.
\end{abstract}

\section{INTRODUCTION}

From strategic and industrial points of view, boron is one of the most important elements in the world. Although the element is not used directly, its compounds have a wide range of applications. Boron is found in nature in the form of metal borates, mostly as sodium, calcium and magnesium borates. Boron compounds are produced from boron-containing ores. Commercially, the most-used compound of boron is boric acid. Boric acid is used in many branches of industry, such as in the medical, pharmaceutical and electronic sectors. Boric acid is also used as a starting material in the preparation of many boron chemicals including synthetic organic borate salts, boron phosphate, fluoroborates, boron tri-halides, borate esters, boron carbide and metal alloys such as ferroboron. Ulexite and colemanite are used as raw materials in the production of boric acid (Çetin et al., 2001; Künkül et al., 2003; Temur et al., 2000).

Most boron minerals, like ulexite, tincal, colemanite and pandermite, include water of crystallization in their composition. They give off such water of crystallization on heating, a process known as dehydration. The dehydration of the hydrated boron minerals is an important preparation stage prior to the production of boron compounds (Erşahan et al., 1995), because transportation costs are reduced and the grade is increased. Besides, the mineral becomes more porous after the calcination process is applied and it is attacked by the leaching reagent more easily when subjected to a leaching process. Therefore, a high rate of extraction of boric acid can be obtained from the calcined mineral.

*To whom correspondence should be addressed 
Ulexite is a sodium-calcium-borate hydrate with a chemical formula of $\mathrm{Na}_{2} \mathrm{O} \cdot 2 \mathrm{CaO} \cdot 5 \mathrm{~B}_{2} \mathrm{O}_{3} \cdot 16 \mathrm{H}_{2} \mathrm{O}$. During the thermal dehydration process, ulexite loses part of its hydration water content, depending upon the dehydration temperature. Erşahan et al.(1995) observed that the dehydration of ulexite began at $100^{\circ} \mathrm{C}$, and the dehydration rate was high up to $230^{\circ} \mathrm{C}$. Above this temperature, the dehydration continued at a quite low rate up to $530^{\circ} \mathrm{C}$, at higher temperatures, there was almost no loss of weight. Şener et al. (2000) reported that amorphisation was observed above $160^{\circ} \mathrm{C}$.

Several studies on the dissolution of ulexite in various solutions can be found in literature. Kocakerim et al. (1993) studied the dissolution kinetics of ulexite in $\mathrm{CO}_{2}$-saturated water. Künkül et al. (1997a) examined the dissolution of thermally dehydrated ulexite in sulfuric acid solutions and determined that the dissolution process fit the firstorder pseudo-homogeneous kinetic model. The dissolution kinetics of ulexite in ammonia solutions saturated with carbon dioxide was investigated by Künkül et al. (1997b). It was found that the dissolution rate of ulexite can be described by a firstorder pseudo-homogeneous reaction. The activation energy of the process was calculated to be approximately $55 \mathrm{~kJ} / \mathrm{mol}$. The dissolution kinetics of ulexite in ammonium chloride (Tekin et al., 1998) and in ammonium sulfate (Künkül et al., 2003) solutions were investigated. In ammonium sulphate solutions, it was determined that the dissolution rate of ulexite can be described by a heterogeneous diffusion-controlled ash or product layer. The activation energy of the reaction was found to be $83.5 \mathrm{~kJ} / \mathrm{mol}$. Dissolution of ulexite in aqueous EDTA solutions was examined by Alkan et al. (2000). Alkan et al. (2004) studied the dissolution kinetics and mechanism of ulexite in oxalic acid solutions and determined that the reaction rate was controlled by product-layer diffusion. The activation energy was calculated to be $59.8 \mathrm{~kJ} / \mathrm{mol}$ for this process. Recently, some studies relating to the leaching kinetics of calcined and uncalcined ulexite have been published in the literature. In these studies, ammonium chloride (Gür et al., 2006; Kucuk, 2006), perchloric acid (Demirkıran and Kunkul, 2007) and ammonium nitrate (Demirkıran, 2007) solutions were used as leaching reagents.

In most of the hydrometallurgical processes, inorganic acids are often used as the leaching reactant. When inorganic acids are used as leaching reagent, some undesired impurities can pass into the leaching media. Also, basic ores cause excess acid consumption in the leaching process. Therefore, more basic lixiviants may be a more attractive extracting agent. For this reason, ammonium salts can be used in the leaching studies of ores. The use of ammonium chloride solution has some advantages. One of the important characteristics of leaching in ammonium chloride solution is that $\mathrm{pH}$ 6.5 is maintained almost constant during the leaching. In addition, ammonium chloride provides chloride ion and the ammonium ions furnish the protons required for the dissolution reaction. When ammonium chloride is used as leachant in the leaching of ulexite, the final solution contains $\mathrm{Na}^{+}$, $\mathrm{Ca}^{2+}$, and $\mathrm{Cl}^{-}$ions in addition to dissolved boric acid. Boric acid is crystallized from the final solution, and $\mathrm{Na}^{+}, \mathrm{Ca}^{2+}$ and $\mathrm{Cl}^{-}$ions remain in the solution.

As mentioned above, the $\mathrm{B}_{2} \mathrm{O}_{3}$ grade of ulexite is increased upon calcination, a porous solid can be obtained, and the material becomes more active chemically. Therefore, the leaching rate of the mineral can increase. In this study, the dissolution kinetics of calcined ulexite at different temperatures was examined in ammonium chloride solutions. The effect of calcination temperature, concentration of solution, reaction temperature and solid-to-liquid ratio were investigated and kinetic parameters are reported.

\section{EXPERIMENTAL}

Ulexite samples were obtained from Kırka, Eskisehir, Turkey. The material was first cleaned from visible impurities. Afterwards, the samples were sieved to obtain different particle size fractions. The original ore sample was analyzed and it was found that the mineral contained $42.08 \% \quad \mathrm{~B}_{2} \mathrm{O}_{3}$, $13.98 \% \mathrm{CaO}, 7.95 \% \mathrm{Na}_{2} \mathrm{O}, 35.98 \% \mathrm{H}_{2} \mathrm{O}$ and $0.17 \%$ insoluble matter.

The aim of this process is essentially to obtain calcined ulexite samples for use in the determination of the relationship between solubulity and calcination. The dehydration of ulexite was performed isothermally in an oven at constant temperatures between $373 \mathrm{~K}$ and $523 \mathrm{~K}$ for different periods of time until the weight loss was practically constant. After putting $1 \mathrm{~g}$ of the sample with particle size fractions of $-0.840+0.420 \mathrm{~mm}$ in a ceramic crucible, the sample was subjected to the given temperature. Following this procedure, the sample was cooled and weighed. For various calcination temperatures and times, the weight loss of sample is presented in Fig.1. This figure shows that the weight loss is quite rapid up to a certain value at each temperature. Thereafter, the weight 
loss is negligible. Therefore, ulexite calcined for 120 min was used in the dissolution tests. At each temperature, the maximum loss of weight (at 180 minutes) and the $\mathrm{B}_{2} \mathrm{O}_{3}$ grade are shown in Fig. 2. It can be seen in this figure that the $\mathrm{B}_{2} \mathrm{O}_{3}$ grade increases with increasing loss of weight. After the calcination tests, the calcined samples were used in the dissolution reactions.

Parameters that were expected to affect the dissolution rate were chosen, including the calcination temperature, solution concentration, reaction temperature, and solid-to-liquid ratio. The ranges of parameters are presented in Table 1. The dissolution experiments were carried out in a $500 \mathrm{~mL}$ cylindrical glass reactor equipped with a mechanical stirrer (a 45-mm-diameter Teflon stirring blade), a reaction temperature control unit (a constanttemperature bath), and a condenser to avoid loss of solution by evaporation. The experimental procedure was as follows: $200 \mathrm{~mL}$ of a $99.5 \%$ pure ammonium chloride solution at a definite concentration were placed in the glass reactor. The reactor jacket was heated to the desired temperature and stirring speed was set. A given amount of calcined solid sample was added to the solution. The dissolution process was carried out for various reaction times. At the end of each reaction, the contents of the reactor were filtered and the amount of $\mathrm{B}_{2} \mathrm{O}_{3}$ in the solution was determined (Scott, 1963). $\mathrm{B}_{2} \mathrm{O}_{3}$ in the solution was analysed titrimetrically using a digital titrator. Since the aqueous solutions of boric acid have too weak of an acidic character, direct titration with a basic solution is not possible. For this reason, mannitol is added to the solution to give weak acid character, thus permitting direct analysis of boric acid by titration with a basic solution like sodium hydroxide.

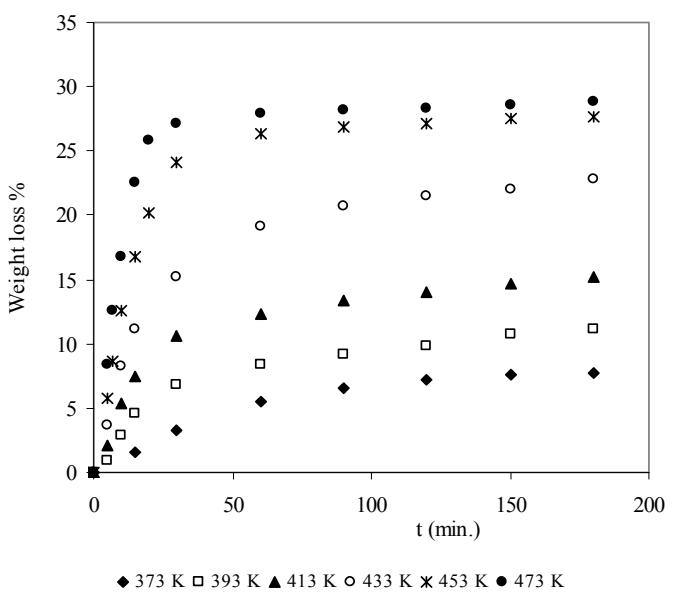

Figure 1: The weight loss of samples for various dehydration temperatures and times

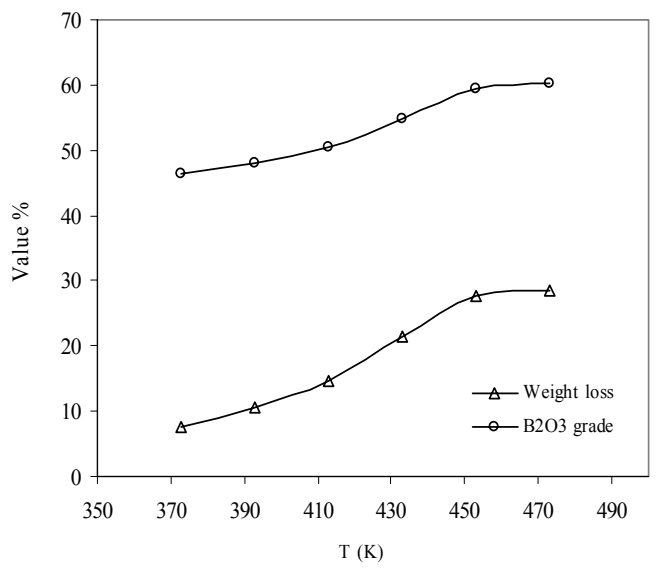

Figure 2: The maximum loss of weight (at 180 min.) and the $\mathrm{B}_{2} \mathrm{O}_{3}$ grade 
Table 1: The ranges of parameters used in the experiments

\begin{tabular}{|c|c|c|c|c|c|c|}
\hline Parameter & \multicolumn{6}{|c|}{ Value } \\
\hline Dehydration temperature, $(\mathrm{K})$ & 373 & 393 & $413^{*}$ & 433 & 453 & 473 \\
\hline Concentration, $(\mathrm{mol} / \mathrm{L})$ & 0.50 & 1.00 & $1.75^{*}$ & 2.50 & & \\
\hline Solid/liquid ratio, $(\mathrm{g} / \mathrm{mL})$ & $1 / 200$ & $2 / 200 *$ & $4 / 200$ & $6 / 200$ & & \\
\hline Temperature, (K) & 298 & 303 & $308^{*}$ & 313 & 318 & \\
\hline Particle size, $(\mathrm{mm})$ & $-0.840+0.420 *$ & & & & & \\
\hline Stirring speed, (rpm) & $400 *$ & & & & & \\
\hline Dehydration time, (min.) & $120 *$ & & & & & \\
\hline
\end{tabular}

* The constant values used when the effect of the parameters was investigated.

\section{RESULTS AND DISCUSSION}

\section{Dehydration and Dissolution Reactions}

During the thermal dehydration process, ulexite loses part of its hydration water content depending upon the dehydration temperature. The dehydration reaction of ulexite is as follows:

$$
\begin{aligned}
& \mathrm{Na}_{2} \mathrm{O} \cdot 2 \mathrm{CaO} \cdot 5 \mathrm{~B}_{2} \mathrm{O}_{3} \cdot 16 \mathrm{H}_{2} \mathrm{O}_{(\mathrm{s})} \rightarrow \\
& \mathrm{Na}_{2} \mathrm{O} \cdot 2 \mathrm{CaO} \cdot 5 \mathrm{~B}_{2} \mathrm{O}_{3} \cdot \mathrm{nH}_{2} \mathrm{O}_{(\mathrm{s})}+(16-\mathrm{n}) \mathrm{H}_{2} \mathrm{O}_{(\mathrm{g})}
\end{aligned}
$$

Where $\mathrm{n}$ is the number of moles of water remaining after dehydration.

Ammonium chloride ionizes in aqueous medium according to the following reactions,

$$
\mathrm{NH}_{4} \mathrm{Cl} \rightleftarrows \mathrm{NH}_{4}^{+}+\mathrm{Cl}^{-}
$$

$$
\mathrm{NH}_{4}^{+}+\mathrm{H}_{2} \mathrm{O} \rightleftarrows \mathrm{NH}_{3}+\mathrm{H}_{3} \mathrm{O}^{+}
$$

When the calcined ulexite is added into the ammonium chloride solution, the reactions occuring during the dissolution process are probably as follows.

$$
\begin{aligned}
& \mathrm{Na}_{2} \mathrm{O} \cdot 2 \mathrm{CaO} \cdot 5 \mathrm{~B}_{2} \mathrm{O}_{3} \cdot \mathrm{nH}_{2} \mathrm{O}_{(\mathrm{s})}+ \\
& (18-\mathrm{n}) \mathrm{H}_{2} \mathrm{O}_{(\mathrm{l})} \rightleftarrows 2 \mathrm{Na}^{+}{ }_{(\mathrm{aq})}+ \\
& 2 \mathrm{Ca}^{2^{+}}{ }_{(\mathrm{aq})}+4 \mathrm{H}_{3} \mathrm{BO}_{3(\mathrm{aq})}+6 \mathrm{~B}(\mathrm{OH})_{4(\mathrm{aq})}^{-} \\
& \mathrm{B}(\mathrm{OH})_{4(\mathrm{aq})}^{-}+\mathrm{H}_{3} \mathrm{O}_{(\mathrm{aq})}^{+} \leftrightarrow \\
& \mathrm{H}_{3} \mathrm{BO}_{3(\mathrm{aq})}+2 \mathrm{H}_{2} \mathrm{O}_{(\mathrm{l})}
\end{aligned}
$$

Thus, the overall reaction can be written as follows.

$$
\begin{aligned}
& \mathrm{Na}_{2} \mathrm{O} \cdot 2 \mathrm{CaO} \cdot 5 \mathrm{~B}_{2} \mathrm{O}_{3} \cdot \mathrm{nH}_{2} \mathrm{O}_{(\mathrm{s})}+6 \mathrm{NH}_{4} \mathrm{Cl}_{(\mathrm{aq})}+ \\
& (12-\mathrm{n}) \mathrm{H}_{2} \mathrm{O} \rightarrow 2 \mathrm{NaCl}_{(\mathrm{aq})}+2 \mathrm{CaCl}_{2(\mathrm{aq})}+ \\
& 6 \mathrm{NH}_{3(\mathrm{aq})}+10 \mathrm{H}_{3} \mathrm{BO}_{3 \text { (aq) }}
\end{aligned}
$$

\section{Effects of Parameters}

The effect of the dehydration temperature on the dissolution rate was examined at 373, 393, 413, 433, 453 , and $473 \mathrm{~K}$, while a concentration of solution of $1.75 \mathrm{~mol} / \mathrm{L}$, a solid-to-liquid ratio of $2 \mathrm{~g} / 200 \mathrm{~mL}$, a reaction temperature of $308 \mathrm{~K}$ and a stirring speed of $400 \mathrm{rpm}$ were kept constant. The results are shown in Fig. 3. It can be seen that the dissolution rate increases with the dehydration temperature up to 413 $\mathrm{K}$ and decreases with the dehydration temperature above this temperature. This behavior can be explained on the basis of the changes in the crystal structure of ulexite that occur during calcination. During the calcination process, ulexite loses more crystalline water at higher temperatures, thus increasing its porosity. At temperatures higher than $413 \mathrm{~K}$, the porosity of ulexite diminishes due to sintering. Sintering can be expected after $413 \mathrm{~K}$, and the sintering rate of ulexite may increase rapidly with increasing calcination temperature. A similar behavior has also been observed by Künkül et al. (1997a), Tekin et al. (1998) and Alkan et al. (2000). Therefore, it appears that there is a direct relation between particle porosity and dissolution rate. In the absence of pores, the fluid does not penetrate easily inwards into the solid matrix.

The effect of ammonium chloride concentration on the dissolution rate was examined at the concentrations of $0.50,1.00,1.75$ and $2.50 \mathrm{~mol} / \mathrm{L}$, while a calcination temperature of $413 \mathrm{~K}$, a solid-toliquid ratio of $2 \mathrm{~g} / 200 \mathrm{~mL}$, a stirring speed of 400 $\mathrm{rpm}$ and a reaction temperature of $308 \mathrm{~K}$ were kept constant. The results are presented in Fig. 4. This 
figure shows that dissolution rate increases with an increase in solution concentration.

To observe the effect of the solid-to-liquid ratio on dissolution rate, the experiments were carried out at $1 / 200,2 / 200,4 / 200,6 / 200 \mathrm{~g} / \mathrm{mL}$. During the experiments, the calcination temperature, the concentration, the stirring speed and the reaction temperature were kept constant at $413 \mathrm{~K}, 1.75 \mathrm{~mol} / \mathrm{L}$, $400 \mathrm{rpm}$, and $308 \mathrm{~K}$, respectively. The results plotted in Fig. 5 show that the dissolution rate decreases with an increase in the solid-to-liquid ratio. This situation can be explained by the increase in the amount of solid per

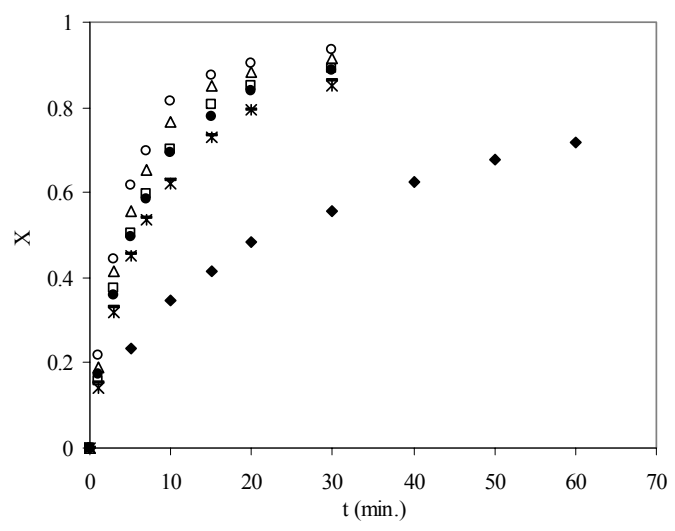

• Uncalcined $\quad \mathrm{3} 73 \mathrm{~K} \quad \Delta 393 \mathrm{~K} \quad \circ 413 \mathrm{~K} \quad \bullet 433 \mathrm{~K} \quad-453 \mathrm{~K} \quad * 473 \mathrm{~K}$

Figure 3: The effect of dehydration temperature on the dissolution rate

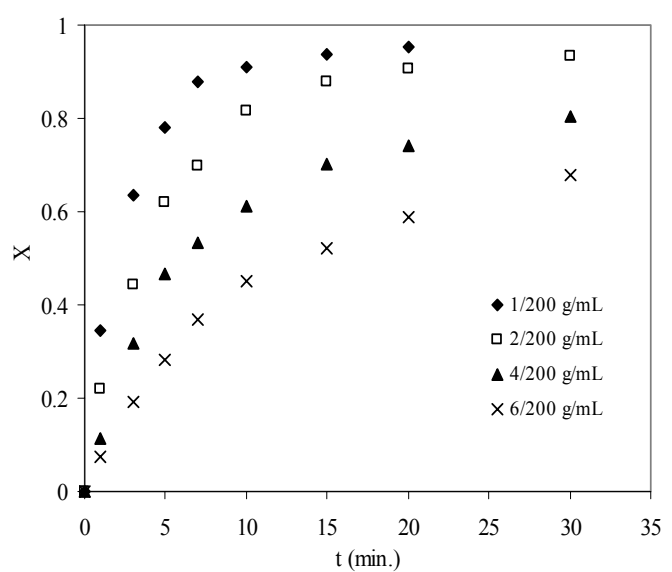

Figure 5: The effect of solid-to-liquid ratio on the dissolution of ulexite amount of reagent in the reaction mixture.

In order to determine the effect of the reaction temperature on the dissolution rate, the experiments were performed with five different reaction temperatures in the range of 298-318 K. The temperature of calcination, the concentration of solution, the solid-to-liquid ratio and the stirring speed were kept constant at $413 \mathrm{~K}, 1.75 \mathrm{~mol} / \mathrm{L}, 2 \mathrm{~g} / 200 \mathrm{~mL}$, and $400 \mathrm{rpm}$, respectively. The experimental results are plotted in Fig. 6. From this figure, it is seen that the conversion rate increases with the reaction temperature.

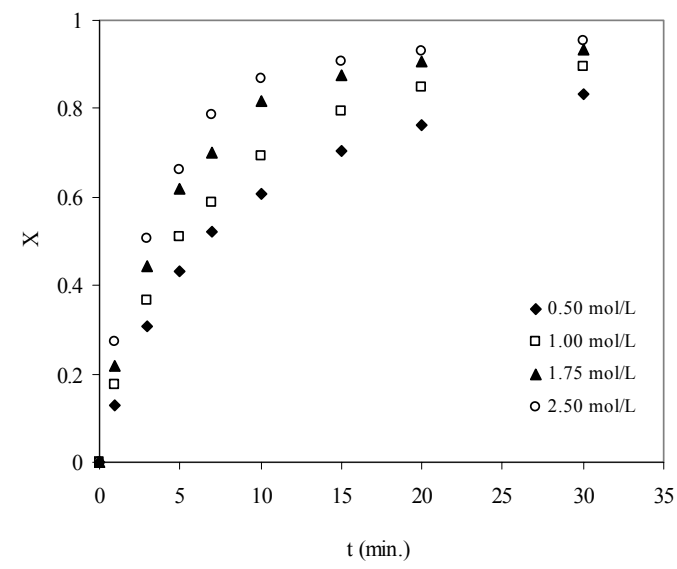

Figure 4: The effect of concentration on the dissolution of ulexite

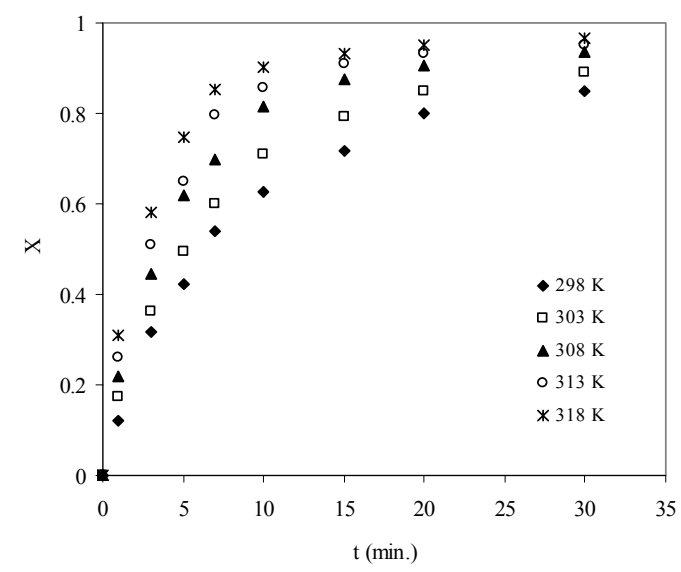

Figure 6: The effect of reaction temperature on the dissolution of ulexite 


\section{Kinetic Analysis}

Fluid-solid heterogeneous reaction systems have many applications in chemical and hydrometallurgical processes. The reaction between a solid and a fluid may be represented by

A(fluid) + b B(solid $) \rightarrow$ Products

The rate of reaction between a solid and a fluid can be expressed by heterogeneous and homogeneous reaction models. According to the shrinking-core model, the reaction is considered to take place at the outer surface of the unreacted particle. When no ash forms, the reacting particle shrinks during reaction, and finally disappears. For a reaction of this kind, the following three steps are considered to occur in succession during reaction (Levenspiel, 1972).

1) Diffusion of the fluid reactant from the main body of the fluid film to the surface of the solid,

2) Reaction on the surface between the fluid reactant and the solid,

3) Diffusion of the products of reaction from the surface of the solid through the fluid film back into the main body of the fluid. Note that the ash layer is absent.

The integrated rate equations can be given as follows if the process is controlled by the resistance of the fluid film (Eq.8) or by the resistance of the surface chemical reaction (Eq.9).

$$
\begin{aligned}
& x=\frac{3 b k_{g} C_{A}}{\rho_{B} R} t \text { (the film diffusion) } \\
& 1-(1-x)^{1 / 3}=\frac{b k_{s} C_{A}}{\rho_{B} R} t
\end{aligned}
$$

(the surface chemical reaction)

In addition to the heterogeneous models, pseudohomogeneous models can also be used to derive the rate equations for the heterogeneous reactions. In pseudo-homogeneous models, the rate equations are written as,

$-\ln (1-\mathrm{x})=\mathrm{kt} \quad$ (for the first-order pseudo-homogeneous model)

$(1-\mathrm{x})^{-1}-1=\mathrm{kt} \quad$ (for the second-order pseudohomogeneous model)
In addition to these models, the Avrami model can also be used.

$-\ln (1-\mathrm{x})=\mathrm{kt}^{\mathrm{m}} \quad$ (for the Avrami model)

The reaction kinetics between calcined ulexite and ammonium chloride solutions were analyzed statistically and graphically by using the shrinkingcore model. When the experimental data obtained were plotted, straight lines passing through the origin were not obtained, and low regression coefficients were found. Therefore, it was determined that the heterogeneous models were inappropriate for this study. The data were then analyzed by using the pseudo-homogeneous models. The plots of the left side of Eq. 10 and 11 versus time must be a straight line if the dissolution follows these models. Similarly the plot of logarithm of the left side of Eq. 12 versus time would be a straight line if the dissolution follows Avrami Model. It was found that the data did not fit the first-order pseudohomogeneous model and the Avrami model. Using the second-order pseudo-homogeneous reaction model, the left side of Eq. 11 was plotted against the reaction time. As can be seen from the plots given in Fig. 7-9, straight lines passing through the origin were obtained. Therefore, the dissolution process was found to follow the second-order pseudohomogeneous model. In accordance with these results, the equation representing the kinetics of this process can be expressed as follows.

$$
(1-\mathrm{x})^{-1}-1=\mathrm{kt}
$$

The dependence of the rate constant on the concentration, solid-to-liquid ratio and reaction temperature may be given by,

$$
\mathrm{k}=\mathrm{k}_{\mathrm{o}}(\mathrm{C})^{\mathrm{a}}(\mathrm{S} / \mathrm{L})^{\mathrm{b}} \exp (-\mathrm{E} / \mathrm{RT})
$$

The rate constant values obtained from Fig. 7-9 were used to calculate the values of the constants a and $b$, in Eq (14). Average calculated values of the constants $\mathrm{a}$ and $\mathrm{b}$ were 0.86 and -1.48 , respectively. To determine the activation energy of the dissolution reaction, the plot of $\ln \mathrm{k}$ versus $1 / \mathrm{T}$ was drawn. It is clear that Fig. 10 shows a straight line. The slope of this line gives the $\mathrm{E} / \mathrm{R}$ value, and the intercept can be used to calculate $k_{0}$. The values of $E / R$ and $k_{0}$ were found to be 7740 and $1.46 \times 10^{8}$, respectively. 
Consequently, the following mathematical model can be written to represent the reaction kinetics of this leaching process

$$
(1-\mathrm{x})^{-1}-1=1.46 \times 10^{8}(\mathrm{C})^{0.86}(\mathrm{~S} / \mathrm{L})^{-1.48} \exp (-7740 / \mathrm{T}) \mathrm{t}
$$

The activation energy of the dissolution reaction was

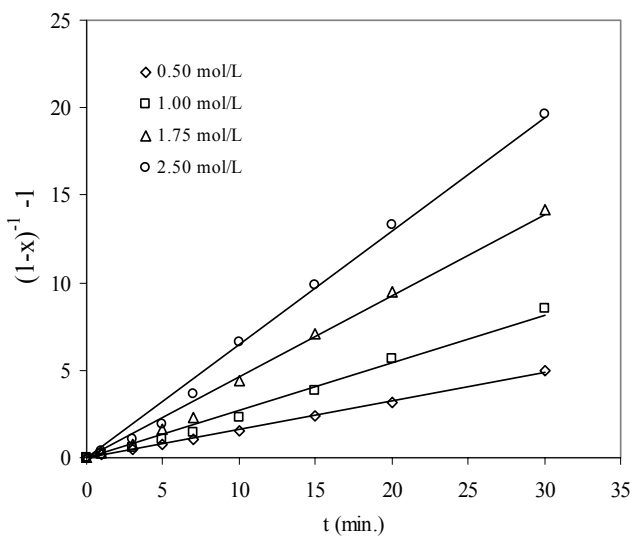

Figure 7: Variation of $(1-\mathrm{x})^{-1}-1$ with time for different concentrations

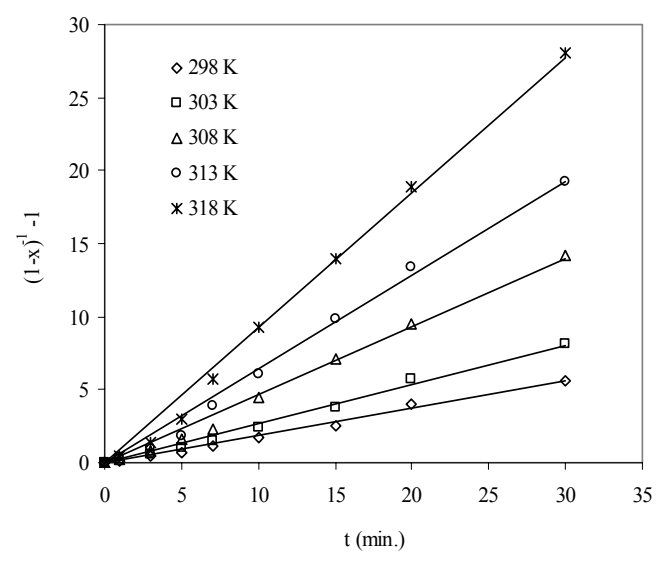

Figure 9: Variation of $(1-x)^{-1}-1$ with time for different reaction temperatures calculated to be $64.35 \mathrm{~kJ} / \mathrm{mol}$.

To test the agreement between the experimental conversion and the values calculated from the mathematical model, the graph of $\mathrm{x}_{\mathrm{exp}}$ versus $\mathrm{x}_{\mathrm{cal}}$ was plotted as shown in Fig. 11. It is observed that the agreement between the experimental and the calculated values is very good.

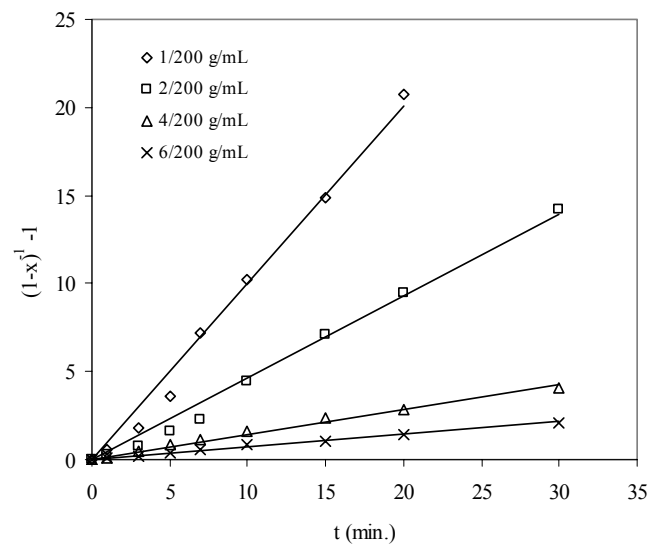

Figure 8: Variation of $(1-\mathrm{x})^{-1}-1$ with time for different solid-to-liquid ratio

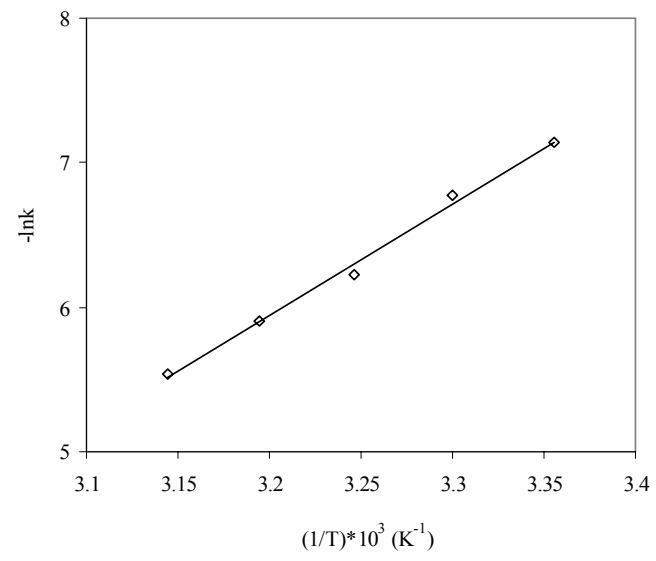

Figure 10: Arrhenius plot for the dissolution of calcined ulexite

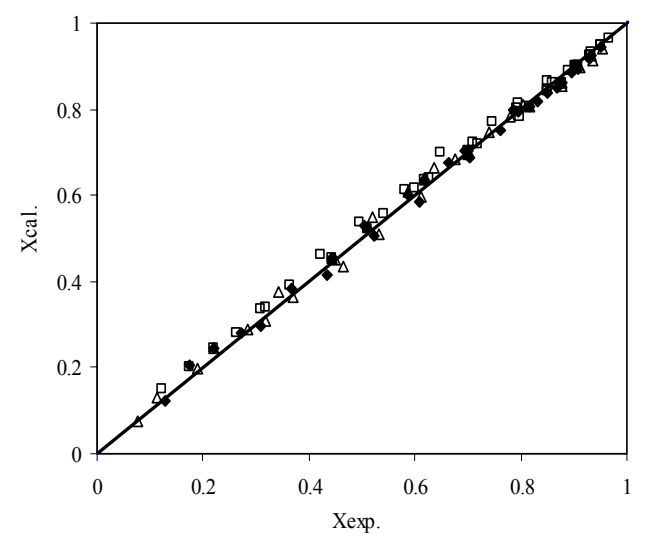

Figure 11: Agreement between experimental and calculated conversion values 


\section{CONCLUSION}

In this work, the dissolution kinetics of calcined ulexite in ammonium chloride solutions was investigated. It was found that the dissolution rate increased with an increase in the dehydration temperature up to $413 \mathrm{~K}$ and decreased with an increase in the dehydration temperature above this temperature. It was determined that the conversion rate increased with an increase in the ammonium chloride concentration, an increase in the reaction temperature, and a decrease in the solid-to-liquid ratio. The dissolution process can be described by the second-order pseudo-homogeneous reaction model. The activation energy of the dissolution reaction was calculated to be $64.35 \mathrm{~kJ} / \mathrm{mol}$.

\section{NOMENCLATURE}

\begin{tabular}{|c|c|c|}
\hline $\mathrm{b}$ & $\begin{array}{l}\text { stoichiometric coefficient } \\
\text { in Eq. } 7\end{array}$ & constant \\
\hline $\mathrm{C}$ & concentration of & $\mathrm{mol} / \mathrm{cm}^{3}$ \\
\hline $\mathrm{C}_{\mathrm{A}}$ & $\begin{array}{l}\text { bulk concentration of the } \\
\text { fluid }\end{array}$ & $\mathrm{mol} / \mathrm{cm}^{3}$ \\
\hline $\mathrm{E}$ & activation energy & $\mathrm{kJ} / \mathrm{mol}$ \\
\hline $\mathrm{S} / \mathrm{L}$ & solid-to-liquid ratio & $\mathrm{g} / \mathrm{mL}$ \\
\hline $\mathrm{R}$ & $\begin{array}{l}\text { average radius of solid } \\
\text { particle }\end{array}$ & $\mathrm{cm}$ \\
\hline $\mathrm{T}$ & temperature & $\mathrm{K}$ \\
\hline $\mathrm{t}$ & reaction time & $\mathrm{s}$ \\
\hline $\mathrm{x}$ & $\begin{array}{l}\text { converted fraction of the } \\
\mathrm{B}_{2} \mathrm{O}_{3}\end{array}$ & $\begin{array}{r}\text { mass fraction, } \\
\mathrm{g} / \mathrm{g}\end{array}$ \\
\hline $\mathrm{k}$ & reaction rate constant & $1 / \mathrm{s}$ \\
\hline $\mathrm{k}_{\mathrm{s}}$ & $\begin{array}{l}\text { rate constant of surface } \\
\text { reaction }\end{array}$ & $\mathrm{cm} / \mathrm{s}$ \\
\hline $\begin{array}{l}\mathrm{a}, \mathrm{b}, \mathrm{k}_{0}, \mathrm{~m} \\
\rho_{\mathrm{B}}\end{array}$ & $\begin{array}{l}\text { constants } \\
\text { molar density of solid } \\
\text { reactant }\end{array}$ & $\mathrm{mol} / \mathrm{cm}^{3}$ \\
\hline
\end{tabular}

\section{REFERENCES}

Alkan, M., Çif̧ci, C., Ayaz, F. and Doğan, M., Dissolution Kinetics of Ulexite in Aqueous EDTA Solutions, Can. Metall. Q. 39, 433 (2000).

Alkan, M., Doğan, M. and Naml, H., Dissolution Kinetics and Mechanism of Ulexite in Oxalic Acid Solutions, Ind. Eng. Chem. Res. 43, 1591 (2004).
Çetin, E., Eroğlu, İ. and Özkar, S., Kinetics of Gypsum Formation and Growth During the

Dissolution of Colemanite in Sulfuric Acid, Journal of Crystal Growth. 231, 559 (2001).

Demirkiran, N., Leaching Kinetics of Calcined Ulexite in Ammonium Nitrate Solutions, J. Chem. Eng. Japan. 40, 755 (2007).

Demirkiran, N. and Künkül, A., Dissolution Kinetics of Ulexite in Perchloric Acid Solutions. Int. J. Miner. Process. 83, 76 (2007).

Erşahan, H., Tunç, M., Ekmekyapar, A. and Yapıcı, S., Flash Dehydration of Ulexite and Investigation of Dehydration Kinetics from Thermogravimetric Data, Thermochimica Acta. 250, 125 (1995).

Gür, A., Yildiz, A. and Ceylan, H., Dissolution Kinetics of Calcined Ulexite in Ammonium Chloride Solutions, Asian Journal of Chemistry. 18, 2002 (2006).

Kucuk, O., Application of Taguchi Method in the Optimization of Dissolution of Ulexite in $\mathrm{NH}_{4} \mathrm{Cl}$ Solutions, Korean J. Chem. Eng. 23, 21 (2006).

Künkül, A., Yapıc1, S., Kocakerim, M. M. and Çopur, M., Dissolution Kinetics of Ulexite in Ammonia Solution Saturated with $\mathrm{CO}_{2}$, Hydrometallurgy. 44, 135 (1997a).

Künkül, A., Tunç, M., Yapıcı, S., Erşahan, H. and Kocakerim, M.M., Dissolution of Thermally Dehydrated Ulexite in Sulfuric Acid Solution, Ind. Eng. Chem. Res. 36, 4847 (1997b).

Künkül, A., Demirkıran, N. and Baysar, A., Dissolution Kinetics of Ulexite in Ammonium Sulfate Solutions, Ind. Eng. Chem. Res. 42, 982 (2003).

Kocakerim, M. M., Çolak, S., Davies, T. and Alkan, M., Dissolution Kinetics of Ulexite in $\mathrm{CO} 2$ Saturated Water, Can. Metal. Q. 32, 393 (1993).

Levenspiel, O., Chemical Reaction Engineering. John Wiley \& Sons, New York (1972).

Scott, W.W., Standart Methods of Chemical Analysis, Van Nostrand, New York (1963).

Şener, S., Özbayoğlu, G. and Demirci, Ş., Changes in the Structure of Ulexite on Heating,

Thermochimica Acta. 362, 107 (2000).

Tekin, G., Onganer, Y. and Alkan, M., Dissolution Kinetics of Ulexite in Ammonium Chloride Solution, Can. Metall. Q. 37, 91 (1998).

Temur, H., Yartaşı, A., Çopur, M. and Kocakerim, M.M., The Kinetics of Dissolution of Colemanite in $\mathrm{H}_{3} \mathrm{PO}_{4}$ Solutions, Ind. Eng. Chem. Res. 39, 4114 (2000). 